\title{
Teachers' Development Approaches of High School Administrators
}

\author{
Necmi Gökyer ${ }^{1, *} \&$ İsmail Türkoğlu ${ }^{1}$ \\ ${ }^{1}$ Faculty of Education, Department of Educational Sciences, Elazig, Turkey \\ *Correspondence: Faculty of Education, Department of Educational Sciences, Firat University, Elazıg, Turkey. Tel: \\ 90-424-237-0000-4941. E-mail: ngokyer@firat.edu.tr
}

Received: June 22, 2018

Accepted: July 21, $2018 \quad$ Online Published: August 24, 2018

doi:10.5430/wje.v8n4p118

URL: https://doi.org/10.5430/wje.v8n4p118

\begin{abstract}
The purpose of this research is to determine the level of teacher development approaches of high school managers, according to their views and the opinions of teachers. The universe of the study constitutes of 2805 teachers in 47 high schools in Elazığ province in 2016-2017 academic year conducted in screening research type. The sample consists of eight schools determined by random sampling method and 356 teachers and 150 managers working in these schools. According to the results of the research, managers use the approaches which are in the sub-dimensions of teacher development activities and the continuous professional development, and the whole scale at the level of "sometimes"; and the approaches which are in sub-dimensionof the educative role of administrators of at the level of "always". According to the views of high school teachers, school administrators use the approaches in the subdimensions of educative role of managers, teacher development activities and in the whole scale at the level of mostly.
\end{abstract}

Keywords: high school, administrators, teacher, development approaches, development, warm-up

\section{Introduction}

\subsection{Introduce the Problem}

Some of the trends emerging in social and educational issues necessitate the change and renewal of schools. These trends also have some important consequences for school leaders. (Sergiovanni, 1996; Dawson, 1997). Principals have significant contributions to the development of educational services at the school (Leithwood, 2005). The fact that school development work is carried out by the stakeholders at school rather than by managers alone, can influence the quality of education positively (Grauwe, 2005). The speed of change and the need to respond and adapt to local conditions require managers to develop new skills and work styles. Managers should be able to lead teachers and students in schools and have the ability to interact with stakeholders inside and outside the education system. If schools are places where development occurs, principals have a key role in designing, monitoring, and evaluating these developments (Mestry and Grabler, 2004).

The role of school principals in the development of teachers; it is very important for managers to observe teachers in place of learning and teaching activities in the classroom, at the seizure places, at the activities they are performing, at club activities, projects and performance duties and to be present at the most basic and most strategic unit of the education system and at all places. Tasks such as giving importance to correction and development in the audit process, supporting teachers' work by making constructive criticisms, teaching them practically when necessary, evaluating the effectiveness of programs, encouraging student learning, monitoring success and raising the motivation levels of employees and keeping the school climate positive are among the educational roles of school principals.

\subsection{Explore Importance of the Problem}

Development is the general improvement and enrichment of an individual's skills and competences through intentional or unintentional learning. It is the process by which individuals acquire knowledge, skills and attitudes through experience, thinking, working or teaching (Buckley and Caple, 2007). Unlike rearing, development is a process involving the evaluation of work experience, relationships, personality and skills, which will help employees to perform effectively in current jobs or organizations, or in future jobs and organizations (Çetin and Özcan, 2012). 
The cultivation and development of human resources within the organization has some benefits for both employees and the organization. When dealt with from the point of view of the employee, raising and development contributes to the employee's ability to do his job effectively. Understanding how to do his/her works as a result of training and development activities, the employee's motivation for work also increases. Employees see that they are doing works more efficiently; this contributes to their feelings of being useful and valuable within the organization.

Employees increase their self-confidence. In addition, another benefit is to support career plans (Currie, 2006; Özdemir, 2014). Training and development also have benefits for the organization. In the process of achieving the organizational goal, an improvement in the quality of human labor will contribute to making organizational affairs more productive and ultimately, to realize the goals of the organization effectively (Özdemir, 2014). Principals have an important role in the effectiveness of the school. The development of educational programs and objectives, the adaptation to environmental developments, and especially the effects of globalization, the expectation of a great variety of tasks from the schools have increased the expectations from the managers and made their work harder. Managers should be able to guide and assist teachers in order to fulfil those duties. In this sense, it has been suggested that managers should be consultants and coaches. It is necessary to be consultants and coaches in various researches about the roles of the administrators (Erdem and Şatır, 2000, Rooney, 2003, Bloom, Castagna and Worren, 2003; Marsh and Lefever, 2004; Goodwin et al. 2005; Cerit, 2008)

In particular, school principals are one of the most important sources in terms of their integration with the education system of the newly appointed candidate teachers, their awareness of their educational functions, their adaptation to the school and the environment they are working with, and their development in education. Occupational development is a concept that is used in common with the concept of in-service training. This concept, which includes the development of the occupation both professionally and personally, requires the recognition of the occupation as an individual, the identification of needs and the fulfillment of those needs. Occupational development is any activity that directly affects the knowledge, skills and attitudes that will enable occupants to perform their current and future roles in the best possible way (Robbins \& Alvy, 1995; Aydin, 2008).

Professional development is a sub-process involved in lifelong education. The concept of professional development has evolved through the evolution of concepts such as in-service training, personnel development, career development, and human resource development. Although conceptual linkage is not provided in the literature, in recent years the concept of in-service training has turned into the concept of vocational education. According to this, the traditional view towards professional development is "a training / course given in 3-4 days" from a new point of view, "staff-centered, long-term, job-embedded learning experiences. According to Guskey, who has been working on the professional development of teachers for many years, "It is the process and activities organized to improve the professional knowledge, skills and attitudes of the educators in order to improve their students (Guskey, 2000; Bumen, Ateş, Çakar, Ural and Acar, 2012). Professional development aims to improve individual performance, to improve inefficient practices, and to facilitate the exchange and change of the application of educational policies (Blandford, 2000).

Below are some teacher development approaches that school principals can use in practice and are used in this study (Aydın, 2008).

1. Warm-Up: Warm-up questions can help teachers express their emotions and thoughts without hesitation and worry about judgment, so that a warm, hearty and reassuring environment can be created to ensure teamwork and co-learning before any intensive group training begins. . For example, "Define a school you want to work for every day, and what kind of school should you want to send your child to?

2. Team building: In order for team work to be done, working groups must first be established. Different methods are used in the establishment of work teams. The principle to be noticed is that each teacher is paired with different individuals during training and that different groups are created in each activity.

3. Reflection Session: Each training session ends with a reflection session. Reflection sessions are usually processes in which the criticism and evaluation of the day are verbally spoken by the individual and feedback about the work is received. In these sessions, the members of the group are sitting in a large circle, expressing opinions and suggestions or self-criticisms about the educational process.

4. Daily Retention: Diaries include the perceptions, expectations, and their fulfillment of the individual's learning process; the difficulties or facilities they experience in terms of interaction and learning within groups; knowledge, skills, attitudes, where they can be used, what they learn and how they learn and express it in writing.

5. Reading Sharing Sessions: Certain sections of pre-determined books are shared among the groups in the direction 
of educational purposes and the group members are asked to identify the main ideas and important messages. The group members discuss the books, articles and similar documents they have studied and present the summarized abstract and summary of the topic to the other groups by writing them on colored pens and with highly creative and remarkable content. Later, if there are questions, they are answered and the session ends.

6. Brain Storming: One of the important features of training is to develop thinking and problem-solving skills in the face of problems or situations that individuals often or rarely encounter. One of the most frequently used activities for this purpose is brain storms. No thought or suggestion in the brain storm work must not be judged and prevented from being judged is the most important principles.

7. Case Study- In Basket: Case study and paper basket techniques are used to develop the skills of teachers to solve the problems they may encounter in their professional lives.

8. Strength Bombardment: The main purpose of this activity is to uncover the strengths of one member of the group perceived by the other members. Such a study provides group members to show positive perceptions about each other's personalities, abilities and skills; the individual to love and develop these difficulties.

9. Peer Assistance Technique P.A.T.: The purpose of this group work is to increase the ability of individuals who are members of colleagues or groups working for specific purposes to help each other in solving a problem or problem and to develop solutions.

10. Host and Guest Groups: These sessions are organized in three phases, and both the host and guest groups have specific tasks.

a. Pre-planning phase: At this stage, the host group creates the working environment, selects the warm-up question and invites the guest group.

b. Planning and implementation phase: At this stage, the host group asks the warm-up questionnaire, the group members meet each other and a warm working environment is provided by taking the answers. Then the host and guest group will discuss the topic, discuss the article, research the book and so on. they give one copy of the writing material to each other. Discussions are held, summarized, workshops prepared by the groups are shared and these work takes about 1 hour.

c. Feedback phase: At this stage the groups express their opinions and suggestions about their work and give feedback on the work.

11. Library Work in Scientific Research: One of the main aims of improvement is to improve teachers' scientific research competencies and the ability to use learning resources effectively.

Changes and anticipations in society make changes and development in schools compulsory. Otherwise, schools lose their effectiveness. In this context, school development is considered as an important concept. School development requires systematic, in-school and out-of-school variables to be looked at in an integrated manner (Everard, Morris and Wilson, 2004, Parlar, 2014, Jones, 2014). The main purpose of school development is to increase the problem-solving capacity of the school (Parlar, 2014). At the same time, it aims to develop appropriate methods and techniques for educating the students in different fields and to obtain applicable results (MEB, 2007).

The dimensions and variables that influence school development are school administrator, teacher, student, school program and education process, school culture and environment, school environment and parents (Şişman, 2011, Cansoy ve Parlar, 2017). It is becoming increasingly important for teachers to demonstrate their professional behavior in schools to achieve this development. The change, development and discussion of teachers' beliefs and practices are influential in school development (Carrington and Elkins, 2002). Teachers' continuous efforts to renew themselves from the professional side, and their activities to develop themselves both inside and outside the school are seen among the important features that provide school development (Şişman, 2011). While the improvement of schools happens in a systematic manner, this improvement is also analogous to individuals' self-improvement (Rolff, 2008). It can be said that the development of schools and the fact that they are effective schools are related to the quality of teachers. Because teachers of influential schools have been found to be more qualified (Mattar, 2012; Hildebrandt and Eom, 2011). Effective school leadership requires school principals to take on an effective leadership role (Mountain, 2009; Shannon and Blysma, 2007), establish academic standards, develop curriculum, ensure teachers' continuous improvement, encourage co-operation and create a safe school climate (Bergeson, Heuschel, Alice and Merle, 2001, Cansoy and Parlar, 2017).

\subsection{Problem Statement}

This research is in the screening model. Scanning models are intended to describe the past or present as it exists. It is 
tried to be defined as an event, an individual or an object, as it is in its own conditions and as it is (Karasar, 2009: 77).

In this context, the aim of this research is to determine the level of teacher development approaches, according to the views of the administrators working in the high schools and the opinions of the teachers. In the research, the following questions have been answered.

\subsection{Sub-problems (Hypotheses)}

1. What are the teachers' views on the approaches of teachers in the development of teachers in high school, in the subscales of the scale and in the scale?

2. Do the teachers' views on high school principals' approaches to the development of teachers differ meaningfully according to variables such as gender, age, occupational seniority, duration of the job at school, branch, level of education and type of high school they work for?

3. What are the views of managers in high school on their approach to developing teachers, in the subscales of the scale and in the whole scale?

4. Do the high school principals' own views on approaches to teacher development differ meaningfully according to gender, age, occupational seniority, length of time in administration, duration of the job at school, branch, level of education and type of high school they work?

\section{Method}

This section contains information on the design of the research, study group, data collection tools, collection and analysis of data.

\subsection{Method of the Research}

This research is in the screening model. Scanning models are intended to describe the past or present as it exists. It is tried to be defined as an event, an individual or an object, as it is in its own conditions and as it is (Karasar, 2009: 77).

\subsection{Data Collection Tools}

The measuring instrument used in the study was formed by the researcher (Gökyer, 2017) with a 25-point pool by conducting the literature search. Created materials presented by three experts in the field. Experts have not commented on the complete removal of any material, but they have recommended that some materials be changed in writing and marking. Data collection tools were graded as "Always (5)," Most often (4), "Occasional (3)," Less (4), "Very few (1). The range of data collection tools is $4 / 5=.80$. Explanatory factor analysis was performed to ensure the validity of the data collection tools. Factor analysis is a statistical technique that aims to explain the measurement by collecting variables that are the same or that measure the quality with few factors (Büyüköztürk, 2009: 123).

\subsection{Reliability and Validity of Data}

In the first part of the measurement tool there are 25 factual questions prepared for the teachers and in the second part, there are 25 items about the approaches on teachers' development of school principals. The suitability of the data for factor analysis was tested by Kaiser-Meyer-Olkin (KMO) and Barlett test. The Bartlett Test = 4322,757 and the validity coefficient $\mathrm{KMO}=.942, \mathrm{p}=.000$. In order to perform factor analysis on the data, the minimum KMO value is suggested as 0.60 (Pullant, 2001). Based on these results, it was determined that data are suitable for factor analysis. As a result of the first exploratory factor analysis for the principles' methods of developing teachers, two items which have factor load score less than 35, and which are present in more than one factor, and difference between the two factors is .10 and lower (Buyüköztürk, 2009: 125) (8./team building and 12. / reading-sharing sessions) were removed from the scale.

The scale of teachers' development approaches of high school administrators has two factors. The total variance explained by the two factors is \% 66,657. The Cronbach's alpha value of the scale is ,96 in general. After factor rotation, the first factor of the scale consists of seven items $(1,2,3,4,5,6,7)$ and the Cronbach Alpha reliability value of this dimension is .92 . The load values of the items in this factor range from 0.667 to 0.867 . The second factor consists of 16 items $(9,10,11,13,14,15,16,17,18,19,20,21,22,23,24,25)$. The Cronbach Alpha reliability value of this dimension is .96 . The load values of the substances in this factor range from 0.602 to 0.854 . Factors have been tried to be named by considering the contents of the materials. The first factor is named as "educational role of managers" and the second factor is named as "teacher development activities of managers". 
To test the 23 items obtained from AFA and whether the result of two factors were verified DFA was applied on a different sample group of 195 individuals and three items (1,21 and 22) with high error variance were subtracted from the scale and the two-dimensional structure was verified with 20 items The model was tested at 0.05 significance level using Maximum Likelihood method. The fit indexes obtained in the first stage are examined. There are different goodness of fit indexes that can be used to assess the suitability of the model. These can be grouped in three: the Chi-square Goodness-of-Fit tests, the Descriptive Measures of Overall Model fit and Descriptive Measures based on Model Comparisons. Whether or not the model is accepted is decided by considering the limit values of these indexes (Schermelleh-Engel and Moosbrugger, 2003).

After selecting the second step, the appropriate estimation method, the results of the model should be analyzed through the fit indexes (Albright and Park 2009). According to the results of various fit indexes in DFA, it is decided whether or not the model is compatible with the theory. Even if the factor loadings of the items in the model are very good, the fit indices may not be able to capture normal values. These fit indixes are named like $\chi^{2}, \chi^{2}$ / sd, RMSEA, SRMR, GFI, NFI, NNFI, CFI. (Munro 2005; Simsek 2007). In the study, it is seen that some of the examined compliance values (NFI, NNFI, CFI) are within the good fit boundaries, while others ( $\chi 2 / \mathrm{df}$, SRMR and RMSEA) are within the acceptable fit boundaries. The fit indices and normal values are shown in Table 1.

Table 1. Fix Indices and Scale Values Fix Indices

\begin{tabular}{llll}
\hline Index & Good fit & Acceptable Fit & Scale Values \\
\hline $\mathrm{X}^{2}($ Chi-square $)$ & $398.77(\mathrm{sd}=165, \mathrm{p}=0.00)$ & \\
$\mathrm{X}^{2} / \mathrm{df}$ & $0 \leq \chi 2 / \mathrm{df} \leq 2$ & $2 \leq \chi 2 / \mathrm{df} \leq 3$ & 2.41 \\
RMSEA & $0 \leq \mathrm{RMSEA} \leq 0.05$ & $0.05 \leq \mathrm{RMSEA} \leq 0.10$ & 0.08 \\
SRMR & $0 \leq \mathrm{SRMR} \leq 0.05$ & $0.05 \leq \mathrm{SRMR} \leq 0.10$ & 0.06 \\
GFI & $\geq 0.95$ & $\geq 0.90$ & 0.83 \\
$\mathrm{NFI}$ & $0.95 \leq \mathrm{NFI} \leq 1.00$ & $0.90 \leq \mathrm{NFI} \leq 0.95$ & 0.96 \\
NNFI & $0.97 \leq \mathrm{NNFI} \leq 1.00$ & $0.95 \leq \mathrm{NNFI} \leq 0.97$ & 0.97 \\
CFI & $0.95 \leq \mathrm{CFI} \leq 1.00$ & $0.90 \leq \mathrm{CFI} \leq 0.95$ & 0.98 \\
\hline
\end{tabular}

The factor loads for the two-dimensional model obtained as the DFA result are shown in Figure 1.

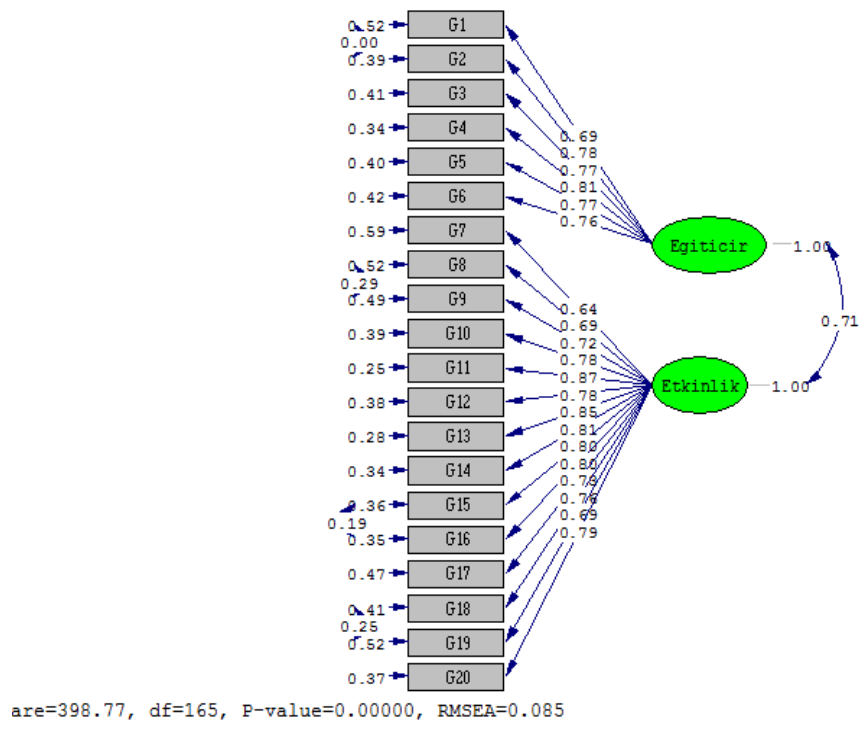

Figure 1. Results of Verification Factor Analysis

The $\mathrm{t}$ values for the two-dimensional model obtained as the DFA result are shown in Figure 2. 


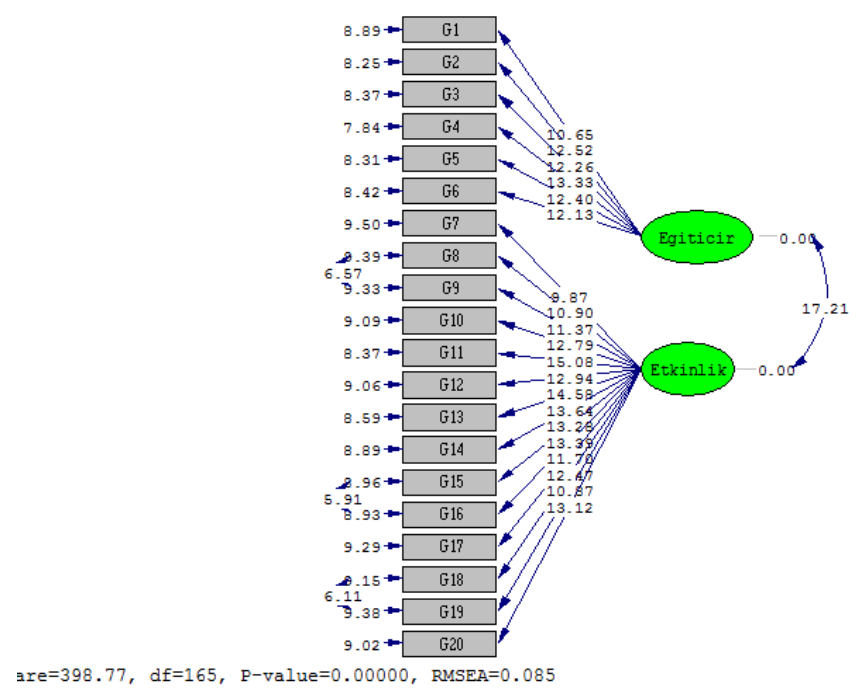

Figure 2. Results of Verification Factor Analysis

In the first part of the measurement scale prepared for the methods of improving the teachers of the school administrators, there are 25 factual questions and in the second part 25 items about the methods of developing the teachers according to their opinions of the school principals. The Bartlett Test $=1291,792$ and the validity coefficient $\mathrm{KMO}=.848, \mathrm{p}=.000$. In the opinion of school principals, according to the results of the first exploratory factor analysis for the scale of teachers' developmental approach, four factors with a difference of 10 or less between the multiple factors (7. /I try to make teachers know each other, 9./ I do reflection sessions to make criticism and evaluation on the work done, 14/ I use the case study technique to improve the ability of teachers to solve the problems they may encounter in their professional life and 20. / partnership cooperative technique) removed from the scale. After the second factor analysis, two items which are present in more than one factor and the difference between them is less than .10 (5./ I create an environment in which has team work and co-operative learning to learn in a collaborative way 16. I learn about the solutions produced by teachers for all kinds of regulations that concern the operation and management of the school using case study technique) removed from the scale. The scale of 25 items fell to 19 items. The scale of teachers' approach to developing teachers according to principles' own opinions is three factors. The total variance explained by the three factors is \% 66,359. Cronbach's Alpha score of the scale is 94 in general. After factoring, the first factor of the scale consists of six items $(1,2,3,4,6,8)$, and the Cronbach Alpha value is .84 . The load values of the items in this factor range from 0.492 to 0.887 . The second factor consists of eight items $(10,11,12$, $13,15,17,18,19)$. The Cronbach Alpha value of this dimension is .92 . The load values of the items in this factor range from 0.586 to 0.840 . The third factor consists of five items $(21,22,23,24,25)$, and the Cronbach Alpha value of this dimension is .88 . The load values of the items in this factor range from 0.545 to 0.871 . Factors have been tried to be named by considering the contents of the materials. The first factor is named as "educational role of the managers", the second factor is named as "teacher development activities of the managers" and the third factor is named as "continuous professional development". To test whether the 19 items and three factors obtained from the AFA were verified, DFA was applied on a different sample group of 222 persons and a three-dimensional structure was verified with 18 items by subtracting an item with a high error variance (item 19) from the scale. Factor load values ares greater than .40 and all $t$ values are meaningful. The fit indices and normal values are shown in Table 2.

Table 2. Fit Indexes and Scale Values Fit Indexes

\begin{tabular}{llll}
\hline Index & Good fit & Acceptable fit & Scale Values \\
\hline $\mathrm{X}^{2}($ Chi-square $)$ & $299.99(\mathrm{sd}=129, \mathrm{p}=0.00)$ & \\
$\mathrm{X}^{2} / \mathrm{df}$ & $0 \leq \chi 2 / \mathrm{df} \leq 2$ & $2 \leq \chi 2 / \mathrm{df} \leq 3$ & 2.32 \\
$\mathrm{RMSEA}$ & $0 \leq \mathrm{RMSEA} \leq 0.05$ & $0.05 \leq \mathrm{RMSEA} \leq 0.10$ & 0.07 \\
SRMR & $0 \leq \mathrm{SRMR} \leq 0.05$ & $0.05 \leq \mathrm{SRMR} \leq 0.10$ & 0.08 \\
GFI & $\geq 0.95$ & $\geq 0.90$ & 0.86 \\
$\mathrm{NFI}$ & $0.95 \leq \mathrm{NFI} \leq 1.00$ & $0.90 \leq \mathrm{NFI} \leq 0.95$ & 0.86 \\
$\mathrm{CFI}$ & $0.95 \leq \mathrm{CFI} \leq 1.00$ & $0.90 \leq \mathrm{CFI} \leq 0.95$ & 0.91 \\
\hline
\end{tabular}




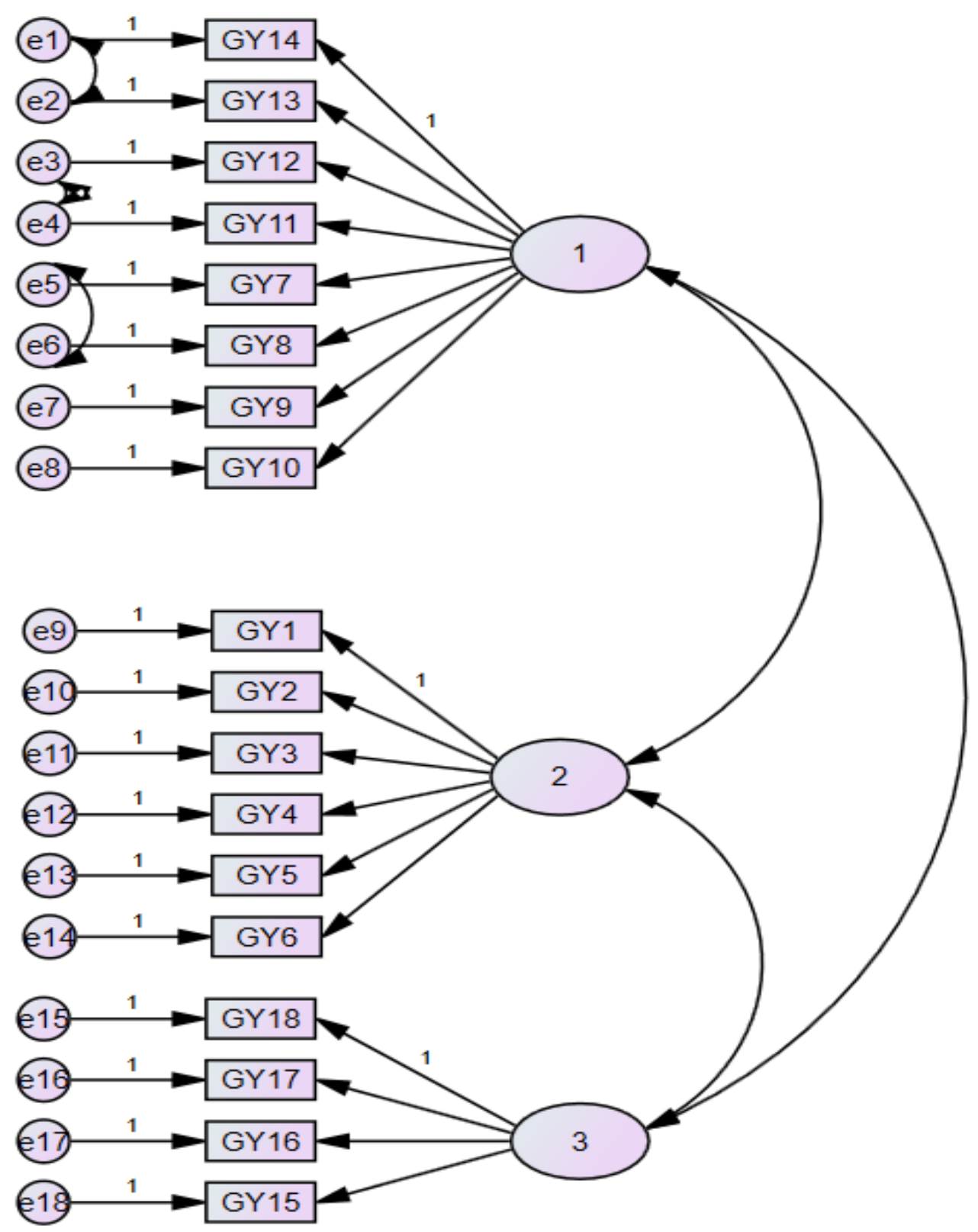

Figure 3. Confirmatory Factor Analysis Results

\subsection{Participant (Subject) Characteristics}

When the demographic characteristics of the teachers participating in the study are examined; \% 38.1 were women ( 85 people), and \% 61.9 (138 people) were male. \% 32.3are in the age group of $23-32$ (72 people), $\% 33.2$ are in the age group of 33-42 (74 people), \%34.5 are in the age group of 43 and over (77 people). $\% 42,0$ (95 persons) $1-10$ years seniority, $\%$ 27,8 (62 persons) 11-20 years seniority, \%23,8 (53 persons) $21-30$ years seniority, $\% 5,8$ (13 people) have a seniority of 31 years and over. In the school where $\% 63.7$ (142 persons) of the teachers were in the school for 1 to 5 years, \%18.4 (41 people) was in 6-10 years, \%5.8 (13 people), \% 12,1 (27 people) is working for 16 years and more. \%48,0 (107 people) are in science and \% 52,0 (116 people) are in social sciences. \%83,4 (186 persons) of the teachers have a bachelor's degree and \%16,6 of them have graduate and doctoral degrees (37 people). $\% 11,7$ are in Science High Schools, \%30,5' (68 persons) are in Anatolian High School, 40.8\% (91 persons) in Vocational High School, 17.0\% (38 persons) in other high schools (multi-program high school).

When the demographic characteristics of the managers participating in the study are examined; $\% 13,7$ were female 
(13 people), \%86,3 (82 people) were male. $\% 14,7$ are $23-32$ years (14 people), $\% 42,1$ are 33-42 years (40 people), $\% 43,2$ are 43 years old and over (41 people). $\% 22,1$ (21 people) have 1-10 years seniority, \% 42,1 (40 people) have 11-20 years seniority, \%31,6 (30 people) have 21-30 years seniority, \%4,2(4 people) have 31 years seniority and over. \%51,6 (49 people) have 1-4 years of managerial period, \% 25,3 (24 people) 5-9 years, \%15,8 (15 people) 10-14 years and \%7,4 (7 people) have 15 years and over managerial period. \%72.6 (69 people) of the administrators have been in the school for 1 to 5 years, \% 17.9 (17 people) for 6-10 years, \% 3,2 (3 people) for 11-15 years, \%6,3 (6 people) 16 years and more. \% 37,9 (36 people) are in science and \% 62,1 (59 people) are in social sciences. \% 69,5 (66 people) have a bachelor's degree and \% 30,5 have graduate and doctoral degrees (29 people). \% 40 (38 people) are in the Anatolian High School, and \% 43,2 (41 people) are working in vocational high schools.

\subsection{Sampling Procedures}

The study's universe constitutes a total of 2805 teachers working in 47 high schools in Elazlğ province in the 2016-2017 academic year. Firstly, stratified (layered) sampling management is used to determine the subgroups in the environment and to represent them in the sample with proportions within the size of the universe (Büyüköztürk, 2016: 86). Later on, the measurement instrument was distributed to 356 teachers working in 8 schools determined by random sampling method from these layers. 223 of the collected scale were evaluated. The table calculated by Can (2014) was used to determine the size of the sample. The homogeneous sample size for the $95 \%$ confidence level in the table list of 5000 people is reported to be 234 persons (Can, 2014: 30). The measurement instrument for teachers' development approaches prepared for the school administrators was distributed to 150 managers working in these schools, but 95 of them were taken into consideration because of being on leave, duty, and reluctant to fill.

\subsection{Analysis Techniques}

The data were analyzed using the SPSS for Windows 21 program. Frequency and percentage values were used to determine the demographic characteristics of the teachers (gender, age, occupational seniority, duration, branch, level of education and type of high school they served). Arithmetic mean and standard deviation techniques were used to determine the levels of teacher opinions. Independent group t-Test was done to determine whether there was a meaningful difference between the opinions expressed in terms of gender, branch and level of education variables. Also, in order to determine whether there is a meaningful difference between their views in terms of age, seniority, duration of duty, and type of high school they worked for, one-way analysis of variance (ANOVA) was used to test whether there is a difference between the groups' averages. Significance level of the applied tests was taken as .05. The Kruskal-Wallis H Test was used when the normality hypothesis of a one-way ANOVA, a parametric test, was not met. The Mann Whitney U Test was also performed to test that the scores did not differ meaningfully from each other

\section{Results}

In this section, according to the opinions of the teachers, findings and comments about the approaches used by the managers in the high schools to improve the teachers are included.

What are the teachers' views on the approaches of teachers in the development of teachers in high school, what are the subscales of the scale and overall scale? The analysis results for the sub-purpose are given in Table 3.

Table 3. Teacher Opinions Regarding Managerial Approaches to Teacher Development

\begin{tabular}{|c|c|c|}
\hline Subdimensions & $\mathrm{X}$ & SS \\
\hline 1. Educator role of managers & 4,00 &, 82 \\
\hline 2. Teacher development activities of managers & 3,21 & 1,00 \\
\hline 3. Whole scale & 3,45 & 88 \\
\hline
\end{tabular}

As seen in Table 3, according to the views of high school teachers, school administrators use approaches that fall within the dimensions of teacher development activities and across the scale often.

Do the teachers'views on high school teachers' approaches to teacher development differ according to gender, branch, and school of graduation? The results of the analysis for the sub-purpose are given in Table 4. 
Table 4. Results of the T-Test on Teachers' Opinions

\begin{tabular}{|c|c|c|c|c|c|c|c|c|}
\hline \multirow{2}{*}{ Sub dimensions } & \multirow{2}{*}{ Variables } & \multirow{2}{*}{$\mathbf{N}$} & \multirow{2}{*}{$\bar{X}$} & \multirow{2}{*}{ SS } & \multicolumn{2}{|c|}{ Levene } & \multirow{2}{*}{$\mathbf{t}$} & \multirow{2}{*}{$\mathbf{p}$} \\
\hline & & & & & $\mathbf{F}$ & $\mathbf{p}$ & & \\
\hline \multirow{2}{*}{ 1.Educator role of managers } & Women & 85 & 4,06 & ,76 & \multirow{2}{*}{1,155} & \multirow{2}{*}{,284 } & \multirow{2}{*}{, 810} & \multirow{2}{*}{,419 } \\
\hline & Men & 138 & 3,97 & ,86 & & & & \\
\hline \multirow{2}{*}{$\begin{array}{l}\text { 2. Teacher development activities of } \\
\text { managers }\end{array}$} & Women & 85 & 3,22 & 95 & \multirow{2}{*}{1,560} & \multirow{2}{*}{,213 } & \multirow{2}{*}{, 149} & \multirow{2}{*}{, 882} \\
\hline & Men & 138 & 3,20 & 1,04 & & & & \\
\hline \multirow{2}{*}{ 3. Whole scale } & Women & 85 & 3,48 &, 82 & \multirow{2}{*}{2,436} & \multirow{2}{*}{, 120} & \multirow{2}{*}{,349 } & \multirow{2}{*}{, 727} \\
\hline & Men & 138 & 3,43 & ,91 & & & & \\
\hline \multirow{2}{*}{ 1.Educator role of managers } & Science & 107 & 3,96 &, 85 & \multirow{2}{*}{, 121} & \multirow{2}{*}{,729 } & \multirow{2}{*}{,- 815} & \multirow{2}{*}{,416 } \\
\hline & Social Sciences & 116 & 4,05 &, 80 & & & & \\
\hline \multirow{2}{*}{$\begin{array}{l}\text { 2. Teacher development activities of } \\
\text { managers }\end{array}$} & Science & 107 & 3,24 & ,95 & \multirow{2}{*}{2,19} & \multirow{2}{*}{, 140} & \multirow[b]{2}{*}{,498 } & \multirow{2}{*}{,619 } \\
\hline & Social Sciences & 116 & 3,18 & 1,05 & & & & \\
\hline \multirow{2}{*}{ 3. Whole scale } & Science & 107 & 3,46 & ,86 & & & & \\
\hline & Social Sciences & 116 & 3,44 &, 89 & 636 &, 426 &, 163 &, 871 \\
\hline & Bachelor's Degree & 186 & 4,01 &, 79 & & & & \\
\hline 1. Educator role of managers & Master and & 37 & 3,95 & ,98 & 2,136 &, 145 & ,408 & ,684 \\
\hline & Doctorates & 31 & & & & & & \\
\hline & Bachelor's Degree & 186 & 3,22 & ,99 & & & & \\
\hline $\begin{array}{l}\text { 2. 1 eacner development activities of } \\
\text { managers }\end{array}$ & Master and & 37 & 3,14 & 1,08 & ,479 & ,490 & ,468 & ,640 \\
\hline & Doctorates & & & & & & & \\
\hline & Bachelor's Degree & 6 & 3,46 & ,86 & & & & \\
\hline lle & $\begin{array}{l}\text { Master and } \\
\text { Doctorates }\end{array}$ & 37 & 3,39 & ,98 & 869 & ,352 & & ,626 \\
\hline
\end{tabular}

As seen in Table 4, there was no meaningful difference between the views of the teachers in the scale and in all of the sub-dimensions according to gender, branch and school variables they graduated from.

Do the teachers' views on the approaches of high school administrators related to developing teachers show a meaningful difference according to age? The ANOVA results for the sub-objective are given in Table 5.

Table 5. Results of ANOVA According to Age, Vocational Seniority, the Job Duration at School and High School Type

\begin{tabular}{|c|c|c|c|c|c|c|c|c|c|c|}
\hline Dimensions & Variables & $\mathrm{N}$ & $\bar{X}$ & $\begin{array}{l}\text { Source } \\
\text { of variance }\end{array}$ & $\begin{array}{l}\text { Sum } \\
\text { of squares }\end{array}$ & $\mathrm{sd}$ & $\begin{array}{l}\text { Squares } \\
\text { Avg. }\end{array}$ & $\mathrm{P}$ & \multicolumn{2}{|c|}{ Difference } \\
\hline & Age & & & & & & & & & \\
\hline \multirow{3}{*}{$\begin{array}{l}\text { 1. Educator role } \\
\text { of managers }\end{array}$} & $23-32$ & 72 & 4,06 & Intergroup & 1,878 & 2 & ,939 & & & \\
\hline & $33-42$ & 74 & 3,87 & Within-group & 150,168 & 220 & ,683 & 1,376 & ,255 & - \\
\hline & 43 and older & 77 & 4,07 & Total & 152,046 & 222 & & & & \\
\hline \multirow{4}{*}{$\begin{array}{l}\text { 2.Teacher } \\
\text { development } \\
\text { activities of } \\
\text { managers }\end{array}$} & $23-32$ & 72 & 3,16 & Intergroup & 1,761 & 2 & ,939 & & & \\
\hline & $33-42$ & 74 & 3,13 & Within-group & 222,882 & 220 &, 683 & ,869,421 & - & \\
\hline & 43 and older & 77 & 3,33 & Total & 224,643 & 222 & & & & \\
\hline & $23-32$ & 72 & 3,44 & Intergroup & 1,557 & 2 & ,779 & & & \\
\hline \multirow[t]{2}{*}{ 3. Whole scale } & $33-42$ & 74 & 3,36 & Within-group & 171,039 & 220 &, 777 & 1,002 & ,369 & - \\
\hline & 43 and older & 77 & 3,56 & Total & 172,597 & 222 & & & & \\
\hline
\end{tabular}

ANOVA results for teachers 'views on high school teachers' approaches to development of teachers show that there is no meaningful difference for all sub-dimensions according to age variable.

Do the Teacher views on high school teachers' approaches to teacher development differ meaningfully according to the variables such as occupational seniority and the duration of the job at school? The Kruskal Wallis $\mathrm{H}$ test results for the sub-objective are given in Table 6. 
Table 6. Kruskal-Wallis H Test Results of Teachers' Views on High School Managers' Teacher Development Approaches

\begin{tabular}{|c|c|c|c|c|c|c|c|c|c|}
\hline \multirow{2}{*}{$\begin{array}{c}\text { Sub } \\
\text { dimensions }\end{array}$} & \multirow[t]{2}{*}{ Variables } & \multirow[t]{2}{*}{$\mathbf{N}$} & \multirow{2}{*}{$\begin{array}{l}\text { Order } \\
\text { average }\end{array}$} & \multirow[t]{2}{*}{ sd } & \multirow[t]{2}{*}{$x^{2}$} & \multirow[t]{2}{*}{$\bar{p}$} & \multicolumn{3}{|c|}{ MWU } \\
\hline & & & & & & & $\mathbf{U}$ & $\mathbf{p}$ & Difference \\
\hline \multicolumn{10}{|c|}{ Professional seniority } \\
\hline \multirow{4}{*}{$\begin{array}{l}\text { Educator role of } \\
\text { managers }\end{array}$} & $1-10$ years & 95 & 51,34 & 3 & \multirow{4}{*}{8,197} & \multirow{4}{*}{, 042} & 317000 & 004 & $1-4$ \\
\hline & 31 years and over & 13 & 77,62 & & & & 517,000 & , & $1-4$ \\
\hline & $11-20$ years & 62 & 35,04 & & & & & & \\
\hline & 31 years and over & 13 & 52,12 & & & & 219,500 & ,010 & $2-4$ \\
\hline \multicolumn{10}{|c|}{ Tenure of Office at school } \\
\hline \multirow{2}{*}{$\begin{array}{l}\text { Educator role of } \\
\text { managers }\end{array}$} & $6-10$ years & 41 & 29,71 & 3 & \multirow{2}{*}{8,562} & \multirow{2}{*}{\multicolumn{2}{|c|}{357,000}} & \multirow{2}{*}{,013 } & \multirow{2}{*}{$2-4$} \\
\hline & 16 years and over & 27 & 41,78 & & & & & & \\
\hline
\end{tabular}

The Kruskal Wallis $\mathrm{H}$ test, which is used to test the meaningfulness of the difference between the scores of a group of a small number of subjects and a variable, is used for the comparison of teachers' views on managers' approaches to teacher development, according to the occupational seniority and duration of the job variables. The Mann Whitney $U$ test, which is used in binary comparisons, is conducted as a result of the difference observed in the sub-dimension of the educational role of managers, according to the variables of occupational seniority and duration of the job. According to the results of this test, it was found that teachers with vocational seniority 1-10 years and 11-20 years had a lower average rank order in the sub-dimension of the educational role of managers than the teachers with vocational seniority of 31 years or more, and the difference is meaningful. It has been found that the teachers with 6-10 years of schooling in the school have lower average in the sub-dimension of educational roles of the managers than the average of teachers with 16 years or more of vocational seniority, and the differences are meaningful. When we consider the time factor of the teachers who have a short duration in the school, it can be said that the managers have not benefited enough from the approaches related to their educational roles. There is no meaningful difference according to the type of high school type that teachers worked.

What is the level of their opinion of the high school administrators' approaches to teacher development in the sub-dimensions and in the whole scale?

Table 7. Managers' Own Opinions Regarding to Managers' Teacher Development Approaches

\begin{tabular}{lrr}
\hline \multicolumn{1}{c}{ Sub dimensions $\quad \mathbf{N}=\mathbf{2 2 3}$} & $\mathrm{X}$ & $\mathbf{S S}$ \\
\hline 1. Educator role of managers & 4,28 &, 60 \\
2. Teacher development activities of managers & 2,72 & 1,00 \\
3. Continuing professional development & 3,07 &, 67 \\
4. Whole scale & 3,30 &, 65 \\
\hline
\end{tabular}

As seen in Table 7, managers use the approaches in sub-dimensions of teacher development activities $(\mathrm{X}=2.72)$, continuous professional development $(\mathrm{X}=3,07)$ and in the whole scale $(\underline{\mathrm{X}}=3.30)$ At the level of occasionally. They use the approaches in the sub-dimension of manager's educational role $(\mathrm{X}=4.28)$ in the level of always.

Do the high school administrators' own views on approaches to developing teachers show meaningful difference according to gender, branch and level of education? The results of the analysis for the sub-purpose are given in Table 8 . 
Table 8. T-test Results According to Variables of Gender, Branches and Learning Levels Regarding Opinions of High School Managers

\begin{tabular}{|c|c|c|c|c|c|c|c|c|}
\hline \multirow{2}{*}{ Sub dimensions } & \multirow{2}{*}{ Variables } & \multirow{2}{*}{$\mathbf{N}$} & \multirow{2}{*}{$\mathrm{X}$} & \multirow{2}{*}{ SS } & \multicolumn{2}{|c|}{ Levene } & \multirow{2}{*}{$\mathbf{t}$} & \multirow[b]{2}{*}{$\mathbf{p}$} \\
\hline & & & & & $\mathbf{F}$ & $\mathbf{p}$ & & \\
\hline \multirow{2}{*}{$\begin{array}{l}\text { 1.Educator role of } \\
\text { managers }\end{array}$} & Woman & 13 & 4,23 & ,49 & \multirow{2}{*}{,389 } & \multirow{2}{*}{, 534} & \multirow{2}{*}{,- 391} & \multirow{2}{*}{,700 } \\
\hline & Man & 82 & 4,29 & 62 & & & & \\
\hline \multirow{4}{*}{$\begin{array}{l}\text { 2.Teacher development } \\
\text { activities of managers } \\
\text { 3.Continuing } \\
\text { professional } \\
\text { development }\end{array}$} & Woman & 13 & 2,91 & 1,06 & \multirow{3}{*}{, 852} & \multirow{3}{*}{, 358} & \multirow{3}{*}{,- 090} & \multirow{3}{*}{,929 } \\
\hline & Man & 82 & 2,69 & ,99 & & & & \\
\hline & Woman & 13 & 3,01 &, 58 & & & & \\
\hline & Man & 82 & 3,08 & ,69 &, 540 &, 464 & ,497 &, 627 \\
\hline \multirow{2}{*}{ 4. Whole scale } & Woman & 13 & 3,35 & ,60 & \multirow{2}{*}{,019 } & \multirow{2}{*}{, 892} & \multirow{2}{*}{,257 } & \multirow{2}{*}{,800 } \\
\hline & Man & 82 & 3,30 & ,66 & & & & \\
\hline \multirow{2}{*}{$\begin{array}{l}\text { 1.Educator role of } \\
\text { managers }\end{array}$} & Science & 36 & 4,18 &, 55 & \multirow{2}{*}{, 098} & \multirow{2}{*}{, 755} & \multirow[b]{2}{*}{$-1,205$} & \multirow[b]{2}{*}{,232 } \\
\hline & $\begin{array}{l}\text { Social } \\
\text { Sciences }\end{array}$ & 59 & 4,33 & ,63 & & & & \\
\hline \multirow{2}{*}{$\begin{array}{l}\text { 2.Teacher development } \\
\text { activities of managers }\end{array}$} & Science & 36 & 2,70 & 1,03 & \multirow{2}{*}{3,546} & \multirow{2}{*}{, 063} & & \\
\hline & $\begin{array}{l}\text { Social } \\
\text { Sciences }\end{array}$ & 59 & 2,72 & ,989 & & & $-1,514$ & ,135 \\
\hline 3.Continuing & Science & 36 & 2,93 & ,77 & 039 & 844 & & \\
\hline $\begin{array}{l}\text { professional } \\
\text { development }\end{array}$ & $\begin{array}{l}\text { Social } \\
\text { Sciences }\end{array}$ & 59 & 3,16 &, 59 & ,039 & , &,- 178 &, 859 \\
\hline & Science & 36 & 3,23 &, 70 & & & & \\
\hline 4. Whole scale & $\begin{array}{l}\text { Social } \\
\text { Sciences }\end{array}$ & 59 & 3,35 & ,62 & ,771 & ,382 &,- 863 & ,391 \\
\hline & Bachelor's & 66 & 4,25 & ,60 & & & & \\
\hline $\begin{array}{l}\text { 1.Educator role of } \\
\text { managers }\end{array}$ & $\begin{array}{l}\text { Degree } \\
\text { Master and }\end{array}$ & 29 & 4,35 &, 61 & ,316 &, 575 &,- 777 & ,441 \\
\hline & Doctorates & & & & & & & \\
\hline 2.Teacher development & Bachelor's & 66 & 2,72 & ,97 & & & & \\
\hline activities of managers & $\begin{array}{l}\text { Degree } \\
\text { Master and } \\
\text { Doctorates }\end{array}$ & 29 & 2,70 & 1,07 & ,381 &, 539 & $-1,471$ &, 146 \\
\hline 3.Continuing & Bachelor's & 66 & 3,01 & ,70 & & & & \\
\hline $\begin{array}{l}\text { professional } \\
\text { development }\end{array}$ & $\begin{array}{l}\text { Degree } \\
\text { Master and } \\
\text { Doctorates }\end{array}$ & 29 & 3,22 &, 59 & 1,640 & ,204 & ,001 & 999 \\
\hline & Bachelor's & 66 & 3,28 & ,63 & & & & \\
\hline 4. Whole scale & $\begin{array}{l}\text { Master and } \\
\text { Doctorates }\end{array}$ & 29 & 3,36 & ,71 & 1,692 & ,197 &,- 575 & ,568 \\
\hline
\end{tabular}

As seen in Table 8, in none of the sub-dimensions and in the whole scale there is no a meaningful difference between the managers' own opinions according to the variables of gender, branch and education levels.

Do the high school administrators' own views on approaches to developing teachers differ meaningfully according to variables such as managerial duration and high school type they work? The Kruskal Wallis H test results for the sub-objective are given in Table 9.

The Kruskal Wallis $\mathrm{H}$ test, which is used to test the meaningfulness of the difference between the scores of a group of a small number of subjects and a variable, is used to compare the opinions of administrators about the development approaches of teachers with regarding to the duration of administration and the type of high school they work. Mann Whitney U test, which is used in binary comparisons, is conducted as a result of the difference observed in the sub dimensions of managers' teacher development activities and continuous professional development according to the variable of managerial period and in the sub-dimension of continuous professional development according to the variable of the high school type in which they work. 
According to the results of this test, it was found that managers whose managerial period is 1-4 years had a lower average rank order in the sub-dimensions of teacher development activities and the continuous professional development when compared to the managers whose managerial period is 15 years, and the difference is meaningful. It was found that the average of the administrators having managerial duration of 1-4 years and 5-9 years in the sub-dimension of teacher development activities is lower than the average of the administrators having managerial duration of 10-14 years and the differences are meaningful. According to the senior high school type variable of seniority year managers' approaches to develop teachers, it was found that the average of the rank order in the continuing professional development sub-dimension of managers working in vocational high school is lower than those who work in high schools and the differences are meaningful. According to this finding, managers working in Anatolian high schools may be more likely to use teachers' developmental approaches than managers who work in vocational high schools. There is no meaningful difference according to age, occupational seniority, and duration of duty in school.

Table 9. Kruskal-Wallis H Test Results According to Managers' Own Opinions Regarding High School Managers' Teacher Development Approaches

\begin{tabular}{|c|c|c|c|c|c|c|c|c|c|}
\hline \multirow[t]{2}{*}{ Sub dimensions } & \multirow[t]{2}{*}{ Variables } & \multirow[t]{2}{*}{$\mathbf{N}$} & \multirow{2}{*}{$\begin{array}{l}\text { Order } \\
\text { average }\end{array}$} & \multirow[t]{2}{*}{ sd } & \multirow[t]{2}{*}{$x^{2}$} & \multirow[t]{2}{*}{$\mathbf{p}$} & \multicolumn{2}{|c|}{ MWU } & \multirow[b]{2}{*}{ Differenc } \\
\hline & & & & & & & $\mathbf{U}$ & $\mathbf{p}$ & \\
\hline \multicolumn{10}{|l|}{ Managerial Time } \\
\hline & $1-4$ years & 49 & 38,10 & & 14,113 &, 001 & 134,000 &, 000 & $1-3$ \\
\hline \multicolumn{10}{|c|}{$\begin{array}{l}\text { 2.Teacher development } \\
\text { activities of managers }\end{array}$} \\
\hline & $10-14$ years & 15 & 66,37 & & & & & & \\
\hline & $1-4$ years & 49 & 40,49 & & 14,748 & ,002 & 89,000 & ,040 & $1-4$ \\
\hline & $\begin{array}{l}15 \text { years and } \\
\text { over }\end{array}$ & 7 & 55,14 & 3 & & & & & \\
\hline & $5-9$ years & 24 & 16,06 & & 7,462 &, 006 & 85,500 &, 006 & \\
\hline & $10-14$ years & 15 & 26,30 & 1 & & & & & $2-3$ \\
\hline & $1-4$ years & 49 & 41,16 & & 7,812 & ,050 & 86,500 & ,034 & $1-4$ \\
\hline \multirow{2}{*}{$\begin{array}{l}\text { 3.Continuing } \\
\text { professional } \\
\text { development }\end{array}$} & & & & 3 & & & & & \\
\hline & $\begin{array}{l}15 \text { years and } \\
\text { over }\end{array}$ & 7 & 65,21 & & & & & & \\
\hline \multicolumn{10}{|c|}{ High school type they work } \\
\hline \multirow{3}{*}{$\begin{array}{l}\text { 3.Continuing } \\
\text { professional } \\
\text { development }\end{array}$} & $\begin{array}{l}\text { Science high } \\
\text { school }\end{array}$ & 16 & 41,91 & & 6,281 & ,043 & 550,000 & ,023 & $2-3$ \\
\hline & $\begin{array}{l}\text { Anatolian high } \\
\text { school }\end{array}$ & 38 & 56,62 & & & & & & \\
\hline & $\begin{array}{l}\text { Vocational } \\
\text { High School }\end{array}$ & 41 & 42,39 & & & & & & \\
\hline
\end{tabular}

\section{Discussion}

In the survey, the level of managers' own opinions and teachers' opinions on the high school managers' teacher development approaches are determined. Also, it has been examined whether the opinions of teachers differ according to gender, age, seniority, duration of school duties, branches, education levels and high school type variables they work in. Findings related to the research have been discussed and supported by the literature. According to the views of high school teachers, managers use the approaches in the sub-dimensions of the educational role of school managers and teacher development activities and across the scale in the level of often. According to a study by Cerit (2008), it has been determined that managers are perceived to be more likely to increase the quality of educational activities, to organize human and material resources in school, to assist teachers and students when they need it, and to guide them. According to the results of the research conducted by Helvaci and 
Aydoğan (2011), it has been found out that the main features of effective school principals under the leadership qualities are giving importance of equality and fairness, having good relationships with their staff, being consistent and stable, being a leader, being open to developments, producing suggestions and solutions, being sensitive to the problems, defending the rights of the personnel, being well-organized and well-educated, and knowing how to act towards students and teachers. According to the research conducted by Sahin (2013), principals should form a long-term development strategy to improve the school; strengthen the communication link between school and environment; ensure that all stakeholders in the school take part in the change process and assume responsibility; inform and lead the people and groups concerned. The school manager must be a leader who applies what he or she has learned, leads in learning, takes decisions in common, sees the need for innovation, reflects on it, offers a trustful and sincere working environment, pursues new vision for the school, tries to present all the technological innovations of the age and accepts as a school as a whole and attempts to realize change initiatives (Beycioğlu and Aslan, 2010). According to research findings made by Cansoy and Parlar (2018), the results of the research revealed that teachers' perception of school-improvement is not at satisfactory level.

In a study by Sheal (1992), a manager gave the following response to teachers' development activities: a good manager is measured not by what he does but by what teachers do. The productivity of the manager is the productivity of the teacher. There are only two ways to improve the performance of teachers. The first is to improve their capacity and the second is to awaken the desire to do better in teaching. When you develop the teacher by educating, you will not only be able to improve their talents but also maket hem be motivated at the same time. The attitudes and behaviors of the managers in the professional development of teachers are also important. In order for school-building efforts to be successful, both school and local managers must be involved in the training, and must be in the role of the guardian for the development of managers (Sparks and Loucks-Horsley, 2007). As Özer (2004) points out, school administrators' awareness and persuasion about the necessity and benefit of professional development activities are of great importance for the professional development of teachers (Bümen, Ates, Çakar, Ural and Acar, 2012).

Recommendations for the results of the research are as follows: 1. The levels of school managers' use of approaches differ according to the type of high school they work in, reasons for this should be searched and in-service training can be organized on topics that are included in sub-dimensions of monitoring and developing teachers' professional development activities. 2. Yöneticiler, öğretmen geliştirme etkinlikleri, sürekli mesleki gelişim alt boyutlarında ve ölçeğin tamamında yer alan yaklaşımları ara sıra düzeyinde kullandıklarını ifade etmişlerdir. Bunun nedenleri araştırılarak hizmet içi eğitimler düzenlenebilir. 2. Managers have stated that they use teacher development activities in the continuing professional development sub-dimensions and on the whole scale at the level of occasionally. In-service trainings can be organized by exploring the reasons for this.

\section{Conclusion}

As regards the approaches of high school administrators to developing teachers, it is clear that among teachers' opinions on the whole scale and in all sub-dimensions; there is no meaningful difference accoding to gender, age, branch, education level and the type of high school they work on. According to the variable of the high school type that they work, managers who work in both high school and vocational high schools use the approaches in the sub-dimension of teacher development activities less than administrators working in Anatolian high schools.

Meaningful differences were found among teachers' views on managers' managerial approaches to teacher development, according to their occupational seniority and the duration of duty at school. In the sub-dimension of managerial role of managers, the level of opinions of teachers with vocational seniority 1-10 years and 11-20 years is lower than those with vocational seniority 31 years and over. In the subscale of managers' educator role, the level of opinions of teachers with 6-10 years of vocational seniority at school is lower than those with 16 years or more. We can say that the teachers with low vocational seniority may say that managers do not make enough efforts and are not sensitive enough to candidate teachers' compliance with the school, in their awareness of their educational duties, teachers' awareness of the developments in the field of education, creating a sincere and reassuring environment that will enable them to learn in a team and collaborative way, teachers' being able to express their feelings and thoughts to the managers easily and recognize the teachers in relation to the approaches pointed out in the items to be investigated. Administrators use the approaches related to the teacher development activities and continuous professional development sub- dimensions and in the whole scale at the level of occasionally; and the approaches in the educator role of managers sub-dimension at the level of always. It has been concluded that, the managers having higher level of seniority at school have higher level of using teacher development approaches; and according to the 
type of high school they work, managers in the vocational high schools use the approaches of the continuous professional development sub-dimension at a lower level than those working in the Anatolian high schools. There is no meaningful difference according to age, occupational seniority, and duration of duty in school.

\section{References}

Ağaoğlu E., Altınkurt, Y., Yılmaz, K., \& Karaköse, T. (2012). Opinions of School Administrators and Teachers on School Administrators' Competencies (Kütahya Province). Education and Science, 37(164), 159-175.

Albright JJ., \& Park H, M. (2009). Confirmatory Factor Analysis Using Amos, LISREL, Mplus, and SAS/STAT CALIS. Bloomington: University Information Technology Services Center for Statistical and Mathematical Computing Indiana University Press, pp.9-13.

Altınkurt, Y. (2007). Strategic Leadership in Educational Organizations and School Leaders' Strategic Leadership Practices (Unpublished Doctorate Thesis). Anadolu University Educational Sciences Institute, Eskişehir.

Aydin, İ. (2008). Auditing in Teaching. Ankara: Pegem Academy.

Aydin, İ. (2011). In-service Training Handbook in the Public and Private Sector. Ankara: Pegem Academy.

Bergeson, T. Heuschel, Alice, M., \& Merle, D. (2001). Middle Level Strategies for School Improvement. A Report from the Washington State Middle Level Task Force. Office of Superintendent of Public Instruction. Retrieved from http://www.k12.wa.us

Beycioğlu, K., \& Aslan, M. (2010). Change and Innovation as Basic Dynamics in School Development: School Administrators and Teachers' Roles. Yüzüncü Yıl University Journal of Education Faculty, VII(I), 153-173.

Bloom, G., Castagna, C., \& Warren, B. (2003). More than Mentors: Principal Coaching. Leadership, May/June, pp. 20-23.

Buckley, R., \& Jim, C. (2007). The Theory and Practice of Training. London: Kogan Page.

Bümen, N. T., Ates, A., Çakar, E., Ural, G., \& Acar, V. (2012). Professional Development of Teachers in the Context of Turkey: Problems and Suggestions. National Education, 194, 31-50.

Büyüköztürk, Ş. (2009). Scientific Research Methods (4th Ed.). Ankara: Pegem Academy.

Can, A. (2014). Quantitative Data Analysis in the Scientific Research Process with SPSS. Ankara: Pegem Academy.

Cansoy, R., \& Parlar, H. (2017). Teacher Professionalism as a Predictor of School Development. Ahi Evran University Kırşehir Education Faculty Magazine (KEFAD), 18(1), 269-289.

Carrington, S., \& Elkins, J. (2002). Bridging the Gap between Inclusive Policy and Inclusive Culture in Secondary Schools. Support for Learning, 17(2), 51-57. https://doi.org/10.1111/1467-9604.00236

Cerit, Y. (2008). Views of Students, Teachers and Administrators on Metaphors Related to the Manager's Concept. Education and Science, 33(147), 3-13.

Cetin, C., \& Ozcan, E. D. (2012). Human Resources Management. Istanbul: Beta Publications.

Currie, D. (2006). Introduction to Human Resources Management. Oxford: Oxford Press. p. 243.

Dawson, G. (1997). Issues and Directions in Preparing School Leaders: Lessons from A Worldwide Web. New South Wales: The Australian College of Education (Monograph No.30).

Duranay, Y. P. (2005). Levels of Efficacy of Secondary School Conditions in School Attributes (Izmir example) (Master Thesis). Pamukkale University Social Sciences Institute, Denizli.

EB (2007). School Development Model, Planned School Development. Ankara: EARGED Presidency.

Erdem, F., \& Şatır, Ç. (2000, May). "Analysis of Cultural Structure in Different Organizations with Metaphors". VIII. National Management and Organization Congress, Erciyes University, Nevşehir

Everard, K.B., Morris, G., \&Wilson, I. (2004). Effective School Management. SAGE Publication.

Grauwe, A. (2005). Improving the quality of education through school-based management: Learning from International Experiences. Review of Education, 51, 269-287. https://doi.org/10.1007/s11159-005-7733-1

Hamilton, D. I., \& Operanma, A. O. (2008). Training, Development and Employee Performance in the Oil and Gas Industry in Nigeria. Europen Journal of Scientific Research, 19(3), 510-520. 
Helvac1, A., \& Aydoğan, İ. (2011). Teacher Opinions on Effective School and Effective School Mission. Usak University Journal of Social Sciences, 4(2), 41-60.

Hildebrandt, S. A., \& Eom, M. (2011). Teacher professionalization: Motivational factors and the influence of age. Teaching and Teacher Education, 27(2), 416-423. https://doi.org/10.1016/j.tate.2010.09.011

Jones, J. (2014). Management Skills in School. SAGE Publication.

Karasar, N. (2009). Scientific Research Methodology. Concepts, Principles, Techniques (4th Ed.). Ankara.

Marsh, D. D., \& Lefever, K. (2004). School Principals as Standards-based Educational Leaders. Educational Management, Administration \& Leadership, 32(4), 387-404. https://doi.org/10.1177/1741143204046494

Mattar, D. M. (2012). Factors affecting the performance of public schools in Lebanon. International Journal of Educational Development, 32(2), 252. https://doi.org/10.1016/j.ijedudev.2011.04.001

Mestry, R., \& Grabler, B. R. (2004). The Training and Development of Principals to Manage Schools Effectively Using Competence Approach. International Studies in Educational Administration, 32(3), 2-19.

Mountain, S. (2009). Determination of the School Development Needs of the Primary Schools in the Province of Istanbul. Ylldiz Technical University (Unpublished post graduate thesis). Istanbul.

Munro, B. H. (2005). Statistical Methods for Health Care Research. Philadelphia: Lippincott Williams \& Wilkins; pp.351-76.

Özdemir, M. (2014). Human Resources Management in Educational Organizations. Theory, Practice and Technique. Ankara: An1 Publishing.

Parlar, H. (2014). School development in all Aspects. Ankara: Nobel Publishing.

Rolff, H. G. (2008). Konzepte und Verfahren der Schulentwicklung. Fernstudium.

Sahin, İ. (2013). Opinions of Primary School Principals on School Development Strategies and Practices. Educational Sciences in Theory and Practice, 13(1), 229-250.

Schermelleh-Engel, K., \& Moosbrugger, H. (2003). Evaluating the Fit of Structural Equation Models: Tests of Significance and Descriptive Goodness-Of-Fit Measures. Methods of Psychological Research Online, 8(2), pp.23-74.

Sergiovanni, T. (1996). Leadership for the Schoolhouse: How Is It Different? Why Is It Important? San Francisco: Jossey-Bass A Wiley Company.

Shannon, G. S., \& Bylsma, P. (2007). Nine Characteristics of High-performing Schools: A Research-based Resource for Schools and Districts to Assist with Improwing Student Learning. Olympia, Washington: Office of the Superintendent of Public Instruction(OSPI).

Simsek, Ö. F. (2007). Introduction to Structural Equation Modeling, Basic Principles and LISREL Practices. Ankara: Equinox, pp.4-22.

Şişman, M. (2011). Search for Excellence in Education. Ankara: Pegem Academy. 